\title{
Kelayakan Media Pembelajaran Praktikum Fisika Teknik Menggunakan Video Tutorial
}

\author{
Susanti H. Hasan ${ }^{* 1}$, Laroma Larumbia ${ }^{2}$ \\ ${ }^{1,2}$ Program Studi Teknik Komputer, Akademi Ilmu Komputer Ternate \\ email: susantihhasan08@gmail.com*1, laromalarumbia@gmail.com²
}

(Received: 25 Oktober 2021 / Accepted: 26 November 2021 / Published Online: 20 Desember 2021)

\begin{abstract}
Abstrak
Masa darurat Covid-19 mengharuskan pelaksanaan pembelajaran secara daring, yang sebelumnya dilaksanakan secara luring. Kondisi seperti ini mengakibatkan perkuliahan fisika teknik mengalami kendala pada proses praktikumnya. Untuk itu tujuan dalam penelitian ini adalah membuat media pembelajaran yang layak dan sederhana serta mudah diakses (menggunakan YouTube) berupa video tutorial pada praktikum fisika teknik. Metode yang digunakan adalah R\&D dengan model ADDIE yang terdiri dari tahap Analysis, Design, Development, Implementation dan Evaluate. Teknik pengumpulan data menggunakan angket skala likert dan dianalisis menggunakan teknik deskriptif kuantitatif. Hasil penelitian menunjukkan produk media pembelajaran praktikum menggunakan video tutorial dinyatakan sangat layak digunakan oleh ahli media dengan presentase 92,5\% dan menurut ahli materi dinyatakan sangat layak dengan presentase $85 \%$ serta hasil dari respon pengguna dinyatakan sangat layak dengan presentase $86,20 \%$. Sehingga praktikum secara daring menggunakan media video tutorial sangat layak digunakan sebagai media pembelajaran fisika.
\end{abstract}

Kata kunci: ADDIE, Fisika Teknik, Praktikum Virtual

\begin{abstract}
The Covid-19 emergency period requires the implementation of online learning, which was previously carried out offline. This condition causes engineering physics lectures to experience problems in the practical process. For this reason, the purpose of this research is to make learning media that is feasible and simple and easily accessible (YouTube) in the form of video tutorials on engineering physics practicum. The method used is $R \& D$ with ADDIE model consisting of Analysis, Design, Development, Implementation and Evaluate stages. Data collection techniques using Likert scale questionnaires and analyzed using quantitative descriptive techniques. The results showed that the practicum learning this product video tutorials was declared very-suitable (VS) for use by media experts with a percentage of $92.5 \%$ and according to material experts, it was stated to be very-feasible (VF) with a percentage of $85 \%$, and the results of user responses were stated to be VF with a percentage of $86.20 \%$. So that online practicum applies this media is very suitable to be implemented as a physic learning media.
\end{abstract}

Keywords: ADDIE, Engineering Physics, Virtual Practicum

\section{PENDAHULUAN}

Pada tanggal 24 maret 2020 Menteri Pendidikan dan Kebudayaan Republik Indonesia mengeluarkan Surat Edaran Nomor 4 Tahun 2020 tentang pelaksanaan kebijakan Pendidikan dalam masa darurat penyebaran Corona Virus Disesase (Covid-19), dalam surat edaran tersebut dijelaskan bahwa proses belajar siswa maupun mahasiswa dilaksanakan di rumah melalui pembelajaran daring (jarak jauh) (Kemendikbud, 2020). Dengan adanya surat edaran tersebut, pembelajaran yang sebelumnya dilakukan secara luring (tatap muka) diganti dengan pembelajaran daring pada masa Covid-19.

Kondisi seperti ini mengakibatkan perkuliahan fisika teknik mengalami kendala pada proses praktikumnya karena mahasiswa harus melakukan praktikum fisika teknik secara 
daring. Untuk itu penulis merancang media pembelajaran secara virtual dengan menggunakan video tutorial agar mahasiswa dapat melakukan praktikum fisika teknik secara mandiri dari rumah dengan memanfaatkan alat dan bahan praktikum yang sederhana dan terjangkau.

Implementasi pendidikan jarak jauh pada pendidikan tinggi yang bertujuan untuk meningkatkan pemerataan akses terhadap pembelajaran yang bermutu atau disebut sistem pembelajaran yang menggunakan internet (daring) (Sadikin \& Hamidah, 2020; Syarifudin, 2020). Pembelajaran daring dapat berjalan dengan baik apabila didukung oleh teknologi informasi seperti media pembelajaran berupa video tutorial. Video tutorial adalah rangkaian gambar hidup yang disajikan oleh seorang pengajar untuk menyampaikan informasi atau materi pembelajaran kepada sekelompok orang, sehingga sekelompok orang tersebut dapat menambah pengetahuannya (Batubara \& Batubara, 2020). Menurut Dwyer dalam bukunya (Sadiman et al., 1996), video mampu merebut 94\% saluran masuknya pesan atau informasi ke dalam jiwa manusia melalui mata dan telinga serta mampu membuat orang pada umumnya mengingat $50 \%$ dari apa yang mereka lihat dan dengar dari tayangan program. Pesan yang disampaikan melaui media video dapat mempengaruhi emosi yang kuat dan juga dapat mencapai hasil yang cepat yang tidak dimiliki oleh media lain. Video tutorial merupakan salah satu media pembelajaran yang mampu meningkatkan pemahaman materi, kreatifitas atau keterampilan dalam praktek, dan efektifitas serta efesiensi penggunaan waktu dalam proses pembelajaran (Mandalika \& Syahril, 2020).

Beberapa peneliti telah mengembangkan media pembelajaran menggunakan video tutorial dengan metode R\&D seperti pada penelitian (Wirasasmita \& Putra, 2018) pengembangan media pembelajaran video tutorial interaktif menggunakan aplikasi Camtasia Studio dan Macromedia Flash, hanya saja pembuatan media pembelajaran ini menggunakan Software sehingga sulit dikembangkan oleh guru maupun dosen yang bukan bidang keahliannya di informatika. Dan penilitian pengembangan media pembelajaran video tutorial untuk meningkatkan keterampilan siswa pada mata pelajaran teknik animasi 2 dimensi dan 3 dimensi yang dilakukan oleh (Sutrisno et al., 2019) sudah lebih sederhana di mana siswa bisa memutar kembali videonya di rumah dengan menggunakan komputer ataupun televisi. Hasil review beberapa artikel jurnal dan literatur menunjukkan bahwa video pembelajaran membawa dampak positif bagi kegiatan belajar peserta didik seperti demonstrasi materi, motivasi, tutorial dan evektivitas waktu (Agustini \& Ngarti, 2020). Sehingga tujuan dalam penelitian ini adalah membuat media pembelajaran yang layak dan sederhana serta mudah diakses (menggunakan YouTube) berupa video tutorial pada praktikum fisika teknik.

\section{METODE}

Penelitian ini menggunakan metode Research and Development $(\mathrm{R} \& \mathrm{D})$ atau disebut juga metode penelitian dan pengembangan, metode ini digunakan untuk menghasilkan produk tertentu dan menguji keefektifan produk tersebut. Penelitian ini menggunakan model ADDIE sebagai model pembelajaran (Mapicayanti et al., 2018; Irawan et al., 2019). Dengan alur penelitian yang ditunjukkan pada gambar 1 .

\section{Tahap analisis (Analysis)}

Pada tahap ini telah dilakukan identifikasi kebutuhan yang dihasilkan dari observasi dan wawancara awal pada mahasiswa program studi Teknik Komputer AIKOM Ternate angkatan 2020 yang telah melakukan pratikum fisika teknik pada semester sebelumnya yaitu semester 1 (satu) tahun ajaran 2020-2021. Observasi dilakukan secara acak untuk mengetahui kondisi mahasiswa dari aspek sikap selama mengikuti pembelajaran praktikum fisika teknik dari dosen secara konvensional. Hasil observasi dan wawancara digunakan untuk menentukan materi dan cara penyampaian yang akan disampaikan pada pengembangan media. 


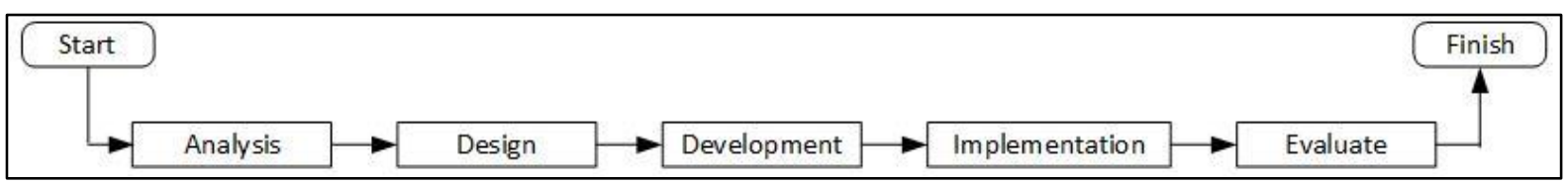

Gambar 1. Alur Penelitian

\section{Tahap Design}

Pada tahap desain atau perancangan produk meliputi penentuan judul dan sub-capaian mata kuliah (sub-cpmk) pada setiap materi pokok praktikum fisika teknik serta mendesain alur video tutorialnya (gambar 2). Pada tahap ini ditetapkan ada 4 materi pokok (judul praktikum) yang digunakan dalam pembuatan media pembelajaran praktikum fisika teknik yaitu: Materi Besaran dan Satuan, Kinematika, Listrik Statis, dan Materi Listrik Dinamis.

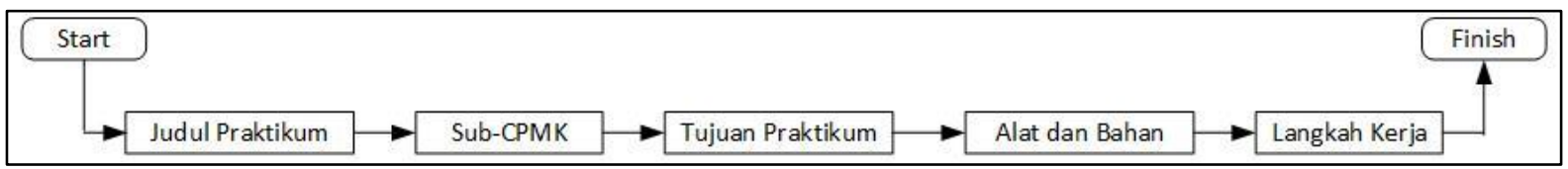

Gambar 2. Tahap Desain Video Tutorial

\section{Tahap Development}

Pada tahap pengembangan meliputi penyusunan modul praktikum dan pembuatan video tutorial. Tahap Penyusunan modul praktikum dimulai dengan menentukan judul praktikum dan sub-cpmk, Selanjutnya dijabarkan tujuan praktikum, teori dasar, alat dan bahan yang dibutuhkan dalam praktikum, langkah kerja, tabel pengamatan serta tugas. Tahap melakukan perekaman video tutorial pada studio mini seperti yang ditunjukkan pada gambar 3 dengan proses editing video menggunakan aplikasi canva

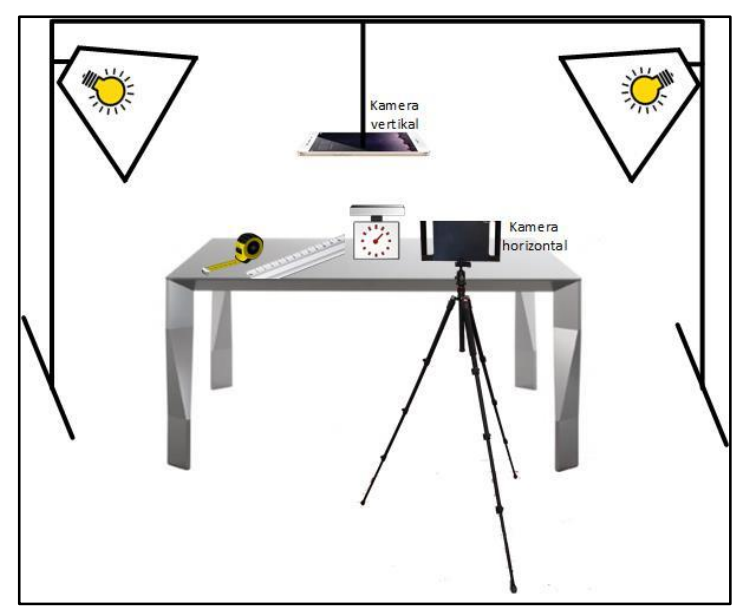

\section{Tahap Implementation}

Gambar 3. Studio Mini

Pada tahap implementasi di mana kegiatan yang dilakukan adalah penerapan produk yang dikembangkan. Di sini produk diujicobakan selama dua kali pertemuan dengan melibatkan mahasiswa semester 1 (satu) program studi Teknik Komputer AIKOM Ternate. Kemudian mahasiswa akan menilai media tersebut dengan menggunakan angket skala likert.

\section{Tahap Evaluate}

Evaluasi yang meliputi validasi produk dan revisi sesuai dengan komentar dan saran dari ahli dan pengguna. Angket akan diberikan kepada ahli media, Ahli materi dan pengguna untuk menilai apakah produk berupa media pembelajaran berbasis video tutorial yang dibuat layak atau tidak. Metode kuesioner (angket skala likert) merupakan suatu daftar yang berisikan rangkaian pertanyaan mengenai suatu masalah atau bidang yang akan diteliti (Narbuko \& 
Achmadi, 2009). Teknik analisis data yang digunakan adalah deskriptif kuantitatif yaitu dengan menganalisis data kuantitatif yang diperoleh dari angket pengujian dari ahli dan pengujian produk pada pengguna (Hakky et al., 2018; Maisiswati et al., 2018). Data Kuantitatif yang berupa angka-angka hasil perhitungan atau pengukuran diproses dengan cara dijumlah kemudian dibandingkan dengan jumlah yang diharapkan sehingga diperoleh presentase kelayakan (Arikunto, 2006). Presentase kelayakan dengan menggunakan rumus sebagai berikut.

$$
\text { Presentase Kelayakan(\%) } \frac{\text { skor diperoleh }}{\text { skor yang diharapkan }} \times 100 \%
$$

Tabel 1. Kategori Pencapaian Kelayakan

\begin{tabular}{cc}
\hline Presentase Pencapaian $(\%)$ & Klasifikasi Kelayakan \\
\hline $\mathbf{8 1}-\mathbf{1 0 0}$ & Sangat layak \\
$\mathbf{6 1}-\mathbf{8 0}$ & Layak \\
$\mathbf{4 1}-\mathbf{6 0}$ & Cukup layak \\
$\mathbf{2 1}-\mathbf{4 0}$ & Kurang layak \\
$\mathbf{0}-\mathbf{2 0}$ & Tidak layak \\
\hline
\end{tabular}

(Arikunto, 2010)

\section{HASIL DAN PEMBAHASAN}

Hasil

Pembuatan video tutorial pada studio mini yang terdapat meja praktek, lampu untuk pencahayaan dan kamera menggunakan smartphone yang terdiri dari dua arah yaitu dari arah atas menghadap ke bawah dan dari arah menyamping. Untuk proses editing video menggunakan aplikasi canva dengan template video dan backsound yang tersedia secara gratis. Hasil media video tutorial untuk praktikum fisika Teknik ditujukan oleh gambar 4.

Tabel 2. Data Presentase Ahli Media

\begin{tabular}{ccc}
\hline Aspek yang Dinilai & Presentase & Kriteria \\
\hline Kualitas Video yang Ditampilkan & $95 \%$ & Sangat layak \\
Kemudahan Pengguna & $90 \%$ & Sangat layak \\
Kejelasan/Keterbacaan & $95 \%$ & Sangat layak \\
Layout Media & $90 \%$ & Sangat layak \\
Rata-rata presentase & $92,50 \%$ & Sangat layak \\
\hline
\end{tabular}

Untuk ahli media terdapat 4 aspek yang dinilai yaitu aspek kualitas video yang ditampilkan, kemudahan pengguna, kejelasan teks atau keterbacaan dan layout media, adapun data penilaian dari ahli media ditunjukkan pada tabel 2 . Berdasarkan tabel 2, penilaian yang dilakukan oleh ahli media dengan melihat pada aspek kualitas video, kemudahan pengguna, kejelasan/keterbacaan, dan layout media diperoleh rata-rata presentasenya sebesar $92,5 \%$ dan termasuk dalam kategori Sangat Layak.

Pada ahli materi terdapat 2 aspek yang dinilai yaitu aspek kelayakan isi dan penyajian, adapun data penilaian dari ahli media ditunjukkan pada tabel 3. Berdasarkan tabel 3, penilaian oleh ahli materi dengan melihat pada aspek kelayakan isi materi, dan penyajian materi diperoleh rata-rata presentasenya sebesar $85 \%$ dan termasuk dalam kategori Sangat Layak.

Selanjutnya, pada pengguna (user) terdapat 3 aspek yang dinilai yaitu aspek tampilan, pengoperasian, dan kemanfaatan, adapun data penilaian dari pengguna ditunjukkan pada tabel 4. Berdasarkan tabel 4 , penilaian oleh pengguna dengan melihat pada aspek tampilan media, 
pengoperasian media, dan kemanfaatan media diperoleh rata-rata presentasenya sebesar 86,20\% dan termasuk dalam kategori Sangat Layak.
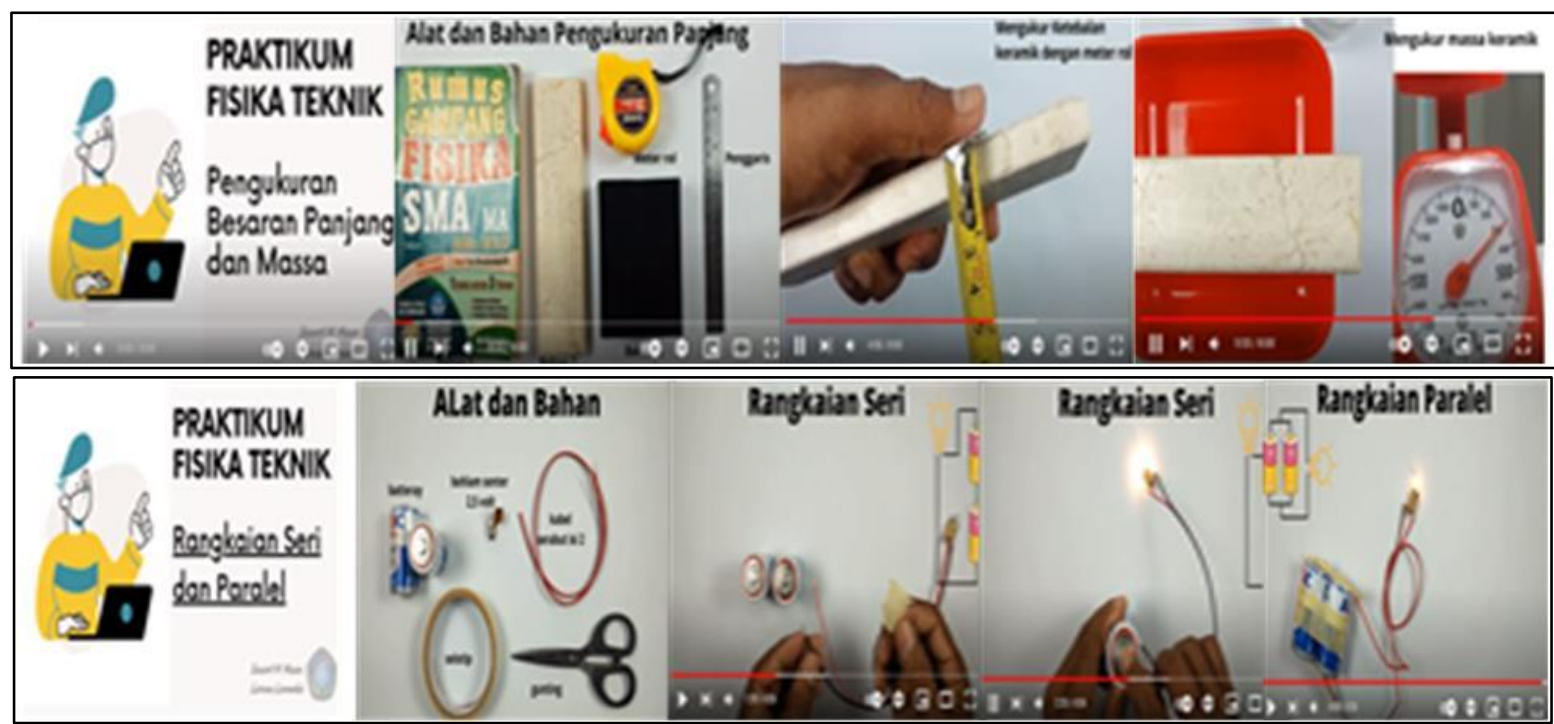

Gambar 4. Video Pembelajaran Praktikum Fisika Teknik

Tabel 3. Data Presentase Ahli Materi

\begin{tabular}{ccc}
\hline Aspek yang Dinilai & Presentase & Kriteria \\
\hline Kelayakan isi & $87,50 \%$ & Sangat layak \\
Penyajian & $82,50 \%$ & Sangat layak \\
Rata-rata presentase & $85 \%$ & Sangat layak \\
\hline
\end{tabular}

Tabel 4. Data Presentase Pengguna

\begin{tabular}{ccc}
\hline Aspek yang Dinilai & Presentase & Kriteria \\
\hline Tampilan Media & $87,41 \%$ & Sangat layak \\
Pengoperasian & $85,17 \%$ & Sangat layak \\
Kemanfaatan & $86,03 \%$ & Sangat layak \\
Rata-rata presentase & $86,20 \%$ & Sangat layak \\
\hline
\end{tabular}

\section{Pembahasan}

Video tutorial untuk praktikum mahasiswa dapat diakses secara daring karena kami telah mengunggah ke situs web berbagi video (YouTube) yang terdiri dari empat video untuk masing-masing praktikum. Dalam setiap video terdapat judul praktikum, sub-cpmk, tujuan praktikum, alat dan bahan serta langkah kerja. Penilaian oleh ahli media dengan presentase yang diperoleh dari kualitas video 95\%, kemudahan 90\%, keterbacaan 95\% dan layout media $90 \%$, sehingga dari keempat aspek tersebut diperoleh rata-rata presentase $92.50 \%$ dengan kriteria sangat layak. Dari ahli materi diperoleh nilai kelayakan isi 87,50\% dan nilai penyajian $82,50 \%$, sehingga dari kedua aspek tersebut diperoleh rata-rata presentase $85 \%$ dengan kriteria sangat layak. Penilaian oleh pengguna pada aspek tampilan media $87,41 \%$, pengoperasian $85,17 \%$ dan kemanfaatan $86,20 \%$, sehingga dari ketiga aspek tersebut diperoleh rata-rata presentase $86,20 \%$ dengan kriteria sangat layak.

Melihat hasil penilaian oleh ahli media, ahli materi paraktikum, dan penilaian pengguna media pembelajaran praktikum dapat disimpulkan bahwa terdapat kesamaan dengan penelitian sebelumnya yaitu media pembelajaran praktikum menggunakan video tutorial ini layak atau cocok digunakan sebagai media pembelajaran yang mengilustrasikan suatu peristiwa yang bergerak, terstruktur, ataupun konsep yang abstrak dan bergerak, hasil ini relevan dengan hasil 
temuan yang dilakukan oleh (Batubara \& Batubara, 2020; Mandalika \& Syahril, 2020). Selain itu, Hasil penelitian dari Chandra dan Nugroho juga menunjukkan bahwa dengan media video, peserta didik dapat berdiskusi dengan teman sekelasnya, menjadi aktif dan termotivasi untuk melakukan praktek mengikuti video tutorial (Chandra \& Nugroho, 2017).

\section{SIMPULAN}

Berdasarkan hasil penelitian dan pembahasan, maka dapat disimpulkan bahwa media pembelajaran berupa video tutorial sangat layak diterapkan pada pembelajaran praktikum khususnya pada praktikum fisika teknik. Hal ini dapat dilihat dari besarnya respon mahasiwa sebagai pengguna sebesar $86,20 \%$ dengan kategori sangat layak untuk video tutorial yang digunakan dalam praktikum. Sehingga media pembelajaran berupa video tutorial perlu dikembangkan karena dapat mendukung pembelajaran jarak jauh (kemudahan akses) serta pembelajaran dapat dilakukan secara mandiri.

\section{REFERENSI}

Agustini, K., \& Ngarti, J. G. (2020). Pengembangan Video Pembelajaran untuk Meningkatkan Motivasi Belajar Siswa Menggunakan Model R\&D. JIPP, 4(1), 62-78. http://dx.doi.org/10.23887/jipp.v4i1.18403.

Arikunto, S. (2006). Prosedur Penelitian Suatu Pendekatan Praktik. Jakarta: Rineka Cipta.

Arikunto, S. (2010). Prosedur Penelitian Suatu Pendekatan Praktik (Revisi 201). Jakarta: Rineka Cipta.

Batubara, H., \& Batubara, D. (2020). Penggunaan Video tutorial untuk Mendukung Pembelajaran Daring Di masa Pandemi Virus Corona. Muallimuna, 5(2), 74-84. http://dx.doi.org/10.31602/muallimuna.v5i2.2950.

Chandra, F., \& Nugroho, W. Y. (2017). Implemntasi FLIPPED Classroom dengan Video Tutorial pada Pembelajaran fotografi Komersial. DEMANDIA, 2(1), 20-36. https://doi.org/10.25124/demandia.v2i01.772.

Hakky, M. K., Wirasasmita, R. H., \& Uska, M. Z. (2018). Pengembangan media pembelajaran berbasis android untuk siswa kelas x pada mata pelajaran sistem operasi. Edumatic: Jurnal Pendidikan Informatika, 2(1), 24-33. https://doi.org/10.29408/edumatic.v2i1.868.

Irawan, U., \& Wirasasmita, R. H. (2019). Media Pembelajaran Video Tutorial Interaktif Berbasis Adobe Flash Pada Mata Kuliah Pemrograman Dasar. Edumatic: Jurnal Pendidikan Informatika, 3(2), 84-90. https://doi.org/10.29408/edumatic.v3i2.1654.

Kemendikbud. (2020). Surat Edaran Dengan No 36962/MPK.A/HK/2020 Tentang Pembelajaran secara Daring dan Bekerja dari Rumah dalam Rangka Pencegahan Penyebaran Corona Virus Disease (COVID-19).

Maisiswati, B. H., Ismatulloh, K., \& Uska, M. Z. (2018). Pengembangan Media Pembelajaran CD Tutorial Interaktif Pada Mata Pelajaran Simulasi Digital. Edumatic: Jurnal Pendidikan Informatika, 2(2), 66-73. https://doi.org/10.29408/edumatic.v2i2.923.

Mandalika, \& Syahril. (2020). Pengembangan Media Pembelajaran Berbasis Video Tutorial Untuk Meningkatkan Efektifitas Pembelajaran Pada Mata Kuliah Tata Rias Pengantin Indonesia. INVOTEK, 20(1), 85-92. https://doi.org/10.24036/invotek.v20i1.725.

Mapicayanti, D., Jamaludin, J., \& Fathoni, A. (2018). Perancangan Media Pembelajaran Berbasis Video Tutorial Mendesain Jaringan Lokal/LAN Kelas X TKJ. Edumatic: Jurnal Pendidikan Informatika, 2(2), 59-65. https://doi.org/10.29408/edumatic.v2i2.913.

Narbuko, C., \& Achmadi, H. (2009). Metodologi Penelitian. Jakarta: Bumi Askara.

Sadikin, A., \& Hamidah, A. (2020). Pembelajaran Daring di Tengah Wabah Covid-19. Biodik, 6(2), 109-119. https://doi.org/10.22437/bio.v6i2.9759

Sadiman, A. S., Rahardjo, R., Haryono, A., \& Rahardjito. (1996). Media Pendidikan: Pengertian Pengembangan dan Pemanfaatannya. Jakarta: Rajawali Pers. 
Sutrisno, Pratama, A., \& Rani, H. A. D. (2019). Pengembangan Media Pembelajaran Video Tutorial untuk Meningkatkan Keterampilan Pada mata Pelajaran Teknik Animasi 2 Dimensi dan 3 Dimensi siswa Jurusan Multemedia SMK Negeri 1 Tonjong. Journal Of Informatics Education, 2(2), 1-6. https://doi.org/10.31331/joined.v2i2.957.

Syarifudin, A. S. (2020). Implementasi Pembelajaran Daring Untuk Meningkatkan Mutu Pendidikan Sebagai Dampak Diterapkannya Social Distancing. Metalingua, 5(1), 31-34. https://doi.org/10.21107/metalingua.v5i1.7072.

Wirasasmita, R. H., \& Putra, Y. K. (2018). Pengembangan Media Pembelajaran Video Tutorial Interaktif menggunakan Aplikasi Camtasia Studio dan Macromedia Flash. Edumatic: Jurnal Pendidikan Informatika, 1(2), 35-43. https://doi.org/10.29408/edumatic.v1i2.944. 